\title{
Article
}

\section{The Local Economic Impact of Shale Gas Extraction}

Whyman, Philip B

Available at http://clok.uclan.ac.uk/17526/

Whyman, Philip B ORCID: 0000-0002-3926-1019 (2017) The Local Economic Impact of Shale Gas Extraction. Regional Studies . pp. 1-13. ISSN 0034-3404

It is advisable to refer to the publisher's version if you intend to cite from the work. http://dx.doi.org/10.1080/00343404.2017.1315395

For more information about UCLan's research in this area go to http://www.uclan.ac.uk/researchgroups/ and search for <name of research Group>.

For information about Research generally at UCLan please go to http://www.uclan.ac.uk/research/

All outputs in CLoK are protected by Intellectual Property Rights law, including Copyright law. Copyright, IPR and Moral Rights for the works on this site are retained by the individual authors and/or other copyright owners. Terms and conditions for use of this material are defined in the policies page.

\section{CLoK}

Central Lancashire online Knowledge www.clok.uclan.ac.uk

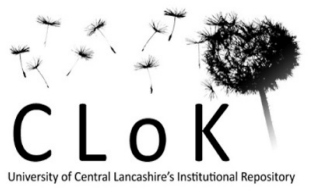




\section{The Local Economic Impact of Shale Gas Extraction}

\section{Philip B. Whyman}

Lancashire Business School, University of Central Lancashire, UK

Professor Philip B. Whyman, Director of the Lancashire Institute for Economic and Business

Research (LIEBR), Lancashire Institute for Economic and Business Research (LIEBR),

Lancashire Business School, University of Central Lancashire, Preston, PR1 2HE.

E-mail: PBWhyman@uclan.ac.uk

Accepted for publication by Regional Studies 


\begin{abstract}
Advocates of UK shale gas expansion have focused upon predicted national economic benefits, but local and/or regional impact has been largely neglected. This paper seeks to address this deficit by creating a unique dataset, combining industry data with consumer and supply chain surveys, thereby overcoming the current absence of suitable secondary data. Local economic impact in the Bowland field is estimated via a simple Keynesian local income multiplier model. Results emphasize the importance of facilitating local employment opportunities, through skills initiatives, and development of regional supply chain clusters, to anchor economic benefits within the local economy. Policy implications are discussed.
\end{abstract}

\title{
Keywords:
}

Local Economic impact

North West Economy

Multiplier

Shale Gas Extraction

Supply Chain

Clustering

JEL: R11, R58, Q48, L78. 


\section{Introduction}

The shale gas industry has been championed by the current UK government due to its potential economic benefits, including predicted employment creation, enhancing energy security, dampening future energy prices and improving the balance of payments through energy exports and/or import-substitution (HCECCC, 2013:25-29; HLEAC, 2014a:9,40). Moreover, it has been suggested that the potential investment expansion might prove to be the catalyst to develop additional industrial clusters or prevent the loss of existing specialism in the field of oil and gas (HCECCC, 2013; HLEAC, 2014b:Ev61).

Possible negative externalities have been acknowledged, particularly relating to the fracturing techniques being employed to release the gas (WOOD et al., 2011:7; GREEN et al., 2012). In addition, it has been suggested that a resource boom might raise wages in the local economy and thereby crowd out some existing production (AlLCOTT AND KENISTON, 2014), albeit that some evidence appears to contradict this hypothesis (MARCHAND, 2012). Consequently, the prevailing view amongst national policy makers, appears to be that, properly regulated, the expansion of the industry would produce a positive net economic benefit for the UK economy. Accordingly, a programme of tax reliefs and other fiscal incentives have been announced to stimulate the development of this industry and consideration of accelerating planning permission for shale gas exploration and extraction has been proposed (HM TREASURY, 2014:35,58; WoOD, 2014). 
Consideration of potential local and/or regional economic impact, however, has been largely neglected. Indeed, in many of the studies completed to date, there is an assumption made that employment opportunities will inevitably benefit the population located spatially close to extraction sites, whilst supply chain expenditure will automatically cause the development of a local energy cluster, thereby benefiting the local population through spending multiplier effects (IOD, 2013:15-6,109,112; HLEAC, 2014a:41-2). Yet, outside a few industry-generated studies, little effort has been made to disaggregate anticipated economic impact to sub-national levels. This omission is the more surprising because, since the UK has a higher population density than the USA, the demonstration of beneficial local economic impact becomes more important to gain the "essential" acceptance of the industry by local communities (IOD, 2013:8; RoDGERS, 2013:5-6; HLEAC, 2014a:29,35,Ev137-9). Moreover, estimation of the local economic impact would allow national policy makers and representatives of the local communities to negotiate an equitable distribution of benefits to mitigate the inevitable costs associated with extraction which will be disproportionately experienced in the area surrounding extraction sites.

Identification of those factors which underpin local economic impact may, additionally, inform local and national policy makers, to allow them to promote regional development in those medium-sized and peripheral regions where shale gas extraction is most likely to occur (Boschma, 2005; MARTIN AND SunLEY, 2006). Compared to larger, organisationally thick and diversified metropolitan regions, medium-sized and peripheral regions have less favourable conditions to promote path renewal and/or new path creation (MARTIN AND SUNLEY, 2006). This disadvantage can be reduced, however, through supportive institutional arrangements to facilitate knowledge absorption and diffusion (MARTIN, 2010). However, path renewal can equally be promoted through the introduction of new firms in new industries (ISAKSEN, 2015). 
Thus, a supportive infrastructure, promoting skills developments, local knowledge spillovers and the embedding of a new regional supply chain for shale gas, could prove to be a catalyst for medium-sized and peripheral regions being locked into more advantageous growth paths (BREKKE, 2015).

This paper, therefore, seeks to make a novel contribution to the evidence base by examining the potential local economic impact which may arise from a planned expansion of shale gas extraction in the Lancashire section of the Bowland-Hodder field. This has been identified by the British Geological Survey as having the greatest potential shale gas reserves in the UK (ANDREWS, 2013). The study utilises internal industry accounts, combined with primary supply chain and consumer survey data, to circumvent the current paucity of secondary data pertaining to the emergent shale gas industry, in order to generate a local economic multiplier estimate utilising a simple Keynesian model. As a result, the paper makes an original contribution to the literature, both in terms of it advancing the first such rigorous estimate of potential local economic impact in the UK, but, perhaps more importantly, by utilising this analysis to identify those policy initiatives which have the potential to secure a greater share of any such impact for the local (host) community.

\section{Background}

Shale gas, alongside coal-bed methane and tight gas sands, are defined as unconventional forms of natural gas. They have the same chemical composition as conventional gas (i.e. methane), but they are distinctive in their low permeability reservoir characteristics, which creates difficulties for the extraction process, typically involving a larger number of production wells. 
In the case of shale gas, this may also necessitate use of horizontal drilling, where the drill shaft represents an 'L' shape, in order to gain better immediate access to gas pockets. This technique can be combined with hydraulic fracturing, which involves pumping a fluid at high pressure into the shale rock, creating fissures which are prevented from closing by adding small particles (i.e. sand and ceramic beads) to the fracturing fluid (GÉNY, 2010:103-7).

The size of shale gas deposits in the UK is a matter of conjecture. The British Geological Survey (BGS), in association with Department of Energy and Climate Change (DECC), have produced provisional estimates for gas in place (GIP) in the Bowland-Hodder field (see Table 1), albeit with the qualification that accuracy can only be confirmed during the drilling phase. Estimates for upper and lower units reflect the divergence between a more explored, condensed upper zone of laterally contiguous, organic-rich material, which is more easily mapped than a deeper, lower unit, extending thousands of feet, which is largely undrilled, but which may hold larger potential reserves.

Table 1: Total Gas in Place Estimates (trillion cubic feet, tcf)

\begin{tabular}{lccc}
\hline & Low (P90) & Central (P50) & High (P10) \\
\hline Upper unit & 164 & 264 & 447 \\
Lower unit & 658 & 1065 & 1834 \\
Total & 822 & 1329 & 2281 \\
(Source: Andrews, 2013:3) & & &
\end{tabular}

Technically or economically recoverable gas reserves are likely to be only a very small proportion (perhaps 10\%) of the GIP forecasts (IOD, 2013:112; HLEAC, 2014a:33,Ev124-5). Hence, based upon the central upper unit GIP, $10 \%$ economic recovery rates (26.4tcf) and current European gas wholesale prices around $\$ 10$ per mmbtu (BOLTON, 2014; HLEAC, 2014a:40,Ev179), this would value industry potential revenue at around $£ 157.1$ billion $(\$ 264$ 
billion). ${ }^{i}$ An alternative estimate made by Cuadrilla Resources, the company licensed to explore the larger part of the Bowland shale, estimates 200tcf GIP, thereby generating a comparable valuation for their exploration field at approximately $£ 119$ billion (\$200 billion). ${ }^{\text {ii }}$ Averaged over a likely twenty year extraction cycle, the latter would represent $£ 5.95$ billion per annum.

To place this into context, the 2014 Gross Value Added (GVA) estimate for the 14 district (NUTS-2) Lancashire economy, was approximately $£ 27.7$ billion; itself the equivalent of $18.5 \%$ of the economy of the North West of England (North West NUTS-1 region). ${ }^{\text {iii }}$ Given that the expansion of the shale gas industry would create new economic activity, both directly but also through its supply chain, it follows that it would have the potential to impart a significant boost to the Lancashire economy, over its likely two decade period of operations (DECC, 2014). The magnitude of this economic benefit to the local economy would, in part, depend upon the proportion of shale gas reserves that proved to be economically viable to extract, the future price of these gas reserves and, of particular relevance to this paper, the degree of leakages arising from a spatially diffuse supply chain.

\section{Estimating the Regional Economic Impact of New Energy Developments}

The standard approaches to estimating economic impact include the calculation of input-output (I-O) multipliers (LEONTIEF, 1986; MILLER and BLAIR, 2009), or utilising social accounting matrix (SAM) or computable general equilibrium (CGE) models which, by their dependence upon I-O accounts for their analysis, may be considered to be extensions or variations of this

general approach (PARTRIDGE AND RICKMAN, 2010:1312; GILMARTIN AND ALLAN, 2015:3412; Allan, 2015:630). Whereas the former seek to model supply chain linkages, and are more 
compatible with a Keynesian demand-determined approach (ACKERMAN, 2002; ROBINSON, 2006), the latter focus upon all monetary flows between economic actors, are founded more firmly upon Walrasian theoretical foundations of continuous market clearing and are considered to have an advantage where capacity constraints and crowding out are considered to be critical features in the analysis (WEST, 1995; ALLAN et al, 2011:1174).

One important insight relevant to estimations of the regional economic impact of new energy developments, drawn from I-O analysis, suggests that the magnitude of the multipliers will be significantly influenced by the degree to which; (i) the expanding sector is embedded within the economy, (ii) labour supply and employment developments in the expanding industry, and (iii) related to expenditure patterns deriving from the household sector (DOMANSKI AND GWOSDZ, 2010).

The weakness with all of these methods, however, is that they depend, to a greater or lesser extent, upon the existence of a reasonably mature industry to facilitate the compilation of I-O data, upon which they all depend. However, in the case of shale gas in the UK, this level of data is not forthcoming, as shale gas is simply too small to be distinguished from existing North Sea oil and gas extraction in official data. Thus, whilst the most recent I-O multiplier estimate for the national (UK) oil and gas sector, which was made in 2010, and suggested that an increase in activity in the oil and gas sector has an output multiplier of 1.416, this related to disproportionately offshore operations (ONS, 2014). The multiplier estimate, therefore, has only a slight relevance to considerations of potential shale gas impact.

A second problem concerns the fact that the Office for National Statistics (ONS) does not produce comparable regional input-output tables, unlike Scotland, where the Scottish 
government produce input-output data for Scotland as a whole, and the USA, where IMPLAN input-output models have estimated regional multipliers for the shale gas industry in Pennsylvania, Ohio and New York, ranging from 1.9 to 2.05 (SNEAD and BARTA, 2008; Considine et al., 2009, 2010; Considine, 2010; WeInStein and PARTRIDGE, 2011). In the absence of regional input-output secondary data, I-O, SAM and CGE analyses must either assume that: (i) a mature offshore energy industry, with a well-established supply chain, will have an impact indistinguishable from an infant, onshore shale gas industry, and that regional economies behave in the same way as the national economy, and thereby use national multipliers; or (ii) alternatively use survey data to estimate supply side and income expenditure, arising from the initial direct stimulus (DOMANSKI and GwOSDZ, 2010:20-32).

Whilst the former approach has been utilised in a number of consultancy reports, its methodology is inappropriate and it produces highly variable estimates of impact (REGENERIS, 2012:47-8; AMEC, 2013:65-6,83-4; IOD, 2013:130; EY, 2014). Consequently, whilst there is a persuasive argument to suggest that I-O and/or CGE modelling will ultimately be able to complement the analysis presented in this paper, once the shale gas industry becomes more established and hence once data availability facilitates this type of analysis, this is not yet the position.

The second alternative indicates that, were the data gleaned from primary and industry sources of sufficient quality, it would be possible for this to be incorporated into an existing I-O table in order to produce economic impact estimates. CONSIDINE (2010) used this approach in his analysis of the US industry, however in this case, survey data was added to pre-existing regional I-O tables (IMPLAN) whereas none exist for the regions of England, which is the focus of this paper. Consequently, this paper utilises a simple Keynesian model to calculate 
multiplier effects, as it can provide broad estimates despite data limitations. ${ }^{\text {iv }}$ This approach is not without its own technical difficulties and requires simplifying assumptions. For example, dynamic effects, such as environmental externalities or displacement costs arising from other industries, impair complete estimation of economic impact (WEINSTEIN and PARTRIDGE, 2011). Nevertheless, the analysis does allow consideration of the shale gas industry, rather than using different types of energy extraction to act as a proxy, and it is able to provide stakeholders and policy makers with a best estimate of the likely consequences of activity, and thereby facilitating appropriate policy response (FAGGIAN and BIAGI, 2003).

\section{Local Income Multiplier - A Simple Keynesian Model}

The simple Keynesian model can be specified using the standard income-aggregate demand expression but applied to a single region, thus:

$\mathrm{Y}_{\mathrm{r}}=\mathrm{C}_{\mathrm{r}}+\mathrm{I}_{\mathrm{r}}+\mathrm{G}_{\mathrm{r}}+\left(\mathrm{X}_{\mathrm{r}}-\mathrm{M}_{\mathrm{r}}\right)$

where $Y_{r}$ represents regional income, $C_{r}$ regional consumption, $I_{r}$ regional investment, $G_{r}$ net regional government expenditure, $\mathrm{X}_{\mathrm{r}}$ regional exports and $\mathrm{M}_{\mathrm{r}}$ regional imports. In this context, exports relate to goods and services produced within the region (i.e. Lancashire), but purchased outside of the region, whether elsewhere in the UK or abroad, whilst imports relate to goods and services produced outside of the region but purchased by residents or firms within the region. 
To take account of the fact that the levels of regional consumption and imports are partially exogenous (independent), and partly a function of regional income, this can be expressed thus:

$\mathrm{C}_{\mathrm{r}}=\overline{\mathrm{Cr}}+\mathrm{cY} \mathrm{r}$

$\mathrm{M}_{\mathrm{r}}=\overline{M r}+m Y_{\mathrm{r}}$

Where $\bar{C}_{\mathrm{r}}$ nd $\bar{M}_{\mathrm{r}}$ reflect exogenous activity and $\mathrm{cY}$ r and $\mathrm{mY}_{\mathrm{r}}$ marginal propensities to consume and import.

To introduce tax leakages from the circular flow of income, the average tax rate $t$ can be applied as:

$Y_{\mathrm{r}}(1-\mathrm{t})$.

Whilst at national level, I is assumed to be exogenous, at regional level, the marginal propensity for businesses to invest may be influenced by the level of regional income, as confidence and the willingness of the financial sector to provide loans to the local business community may depend upon the strength of the local economy (DOW and RODRIGUEZ-FUETES, 1997). Hence:

$\mathrm{I}_{\mathrm{r}}=\bar{I}_{\mathrm{r}}+\mathrm{i} \mathrm{Y}_{\mathrm{r}}(1-\mathrm{t})$

If simplifying assumptions are made, that $\mathrm{G}_{\mathrm{r}}$ and $\mathrm{X}$ are exogenous, then the initial equation can be rewritten as:

$\mathrm{Y}_{\mathrm{r}}=\bar{C}_{\mathrm{r}}+\mathrm{c} \mathrm{Y}_{\mathrm{r}}(1-\mathrm{t})+\bar{I}_{\mathrm{r}}+\mathrm{i} \mathrm{Y}_{\mathrm{r}}(1-\mathrm{t})+\mathrm{G}_{\mathrm{r}}+\mathrm{X}_{\mathrm{r}}-\bar{M}_{\mathrm{r}}-\mathrm{m} \mathrm{Y}_{\mathrm{r}}(1-\mathrm{t})$ 
This can become:

$\mathrm{Y}_{\mathrm{r}}-\mathrm{c} \mathrm{Y}_{\mathrm{r}}(1-\mathrm{t})+\mathrm{i} \mathrm{Y}_{\mathrm{r}}(1-\mathrm{t})+\mathrm{m} \mathrm{Y}_{\mathrm{r}}(1-\mathrm{t})=\bar{C}_{\mathrm{r}}+\bar{I}+\mathrm{G}_{\mathrm{r}}+\mathrm{X}_{\mathrm{r}}-\bar{M}_{\mathrm{r}}$

And

$$
\mathrm{Y}_{\mathrm{r}}=\frac{\bar{C}_{\mathrm{r}}+\mathrm{I}_{\mathrm{r}}+\mathrm{G}_{\mathrm{r}}+\mathrm{X}_{\mathrm{r}}-\bar{M}_{\mathrm{r}}}{1-(\mathrm{c}-\mathrm{m}+\mathrm{i})(1-\mathrm{t})}
$$

Hence, regional income $\mathrm{Y}$ is the sum of exogenous demand multiplied by the regional multiplier k:

$\mathrm{Y}_{\mathrm{r}}=\mathrm{k}\left(\bar{C}_{\mathrm{r}}+\mathrm{I}_{\mathrm{r}}+\mathrm{G}_{\mathrm{r}}+\mathrm{X}_{\mathrm{r}}-\bar{M}_{\mathrm{r}}\right)$

Where

$$
\mathrm{k}=\frac{1}{1-(\mathrm{c}-\mathrm{m}+\mathrm{i})(1-\mathrm{t})}
$$

It follows, from this, that the greater the marginal propensity to consume local goods and services, the greater the proportion of any initial boost in aggregate demand will be retained within the area during subsequent rounds of income circulation. Regions with under-developed local suppliers will result in higher leakage rates, as goods and services are imported from outside the area, and there will be a smaller local economic impact arising from an initial boost 
to demand. The extent of inter-firm linkages, therefore, has a significant impact upon the impact of regional multiplier. Agglomeration research would suggest that access to wellestablished supply chains would disproportionately benefit more established firms, with relatively standardised products, whereas younger and smaller firms gain most from access to local specialisation in skilled labour and knowledge spillovers (AUDRETSCH and FELDMAN, 1996; RigBY AND BROWN, 2015).

\section{Bowland Shale Supply-Chain Study}

In order to correct for the paucity of suitable secondary data relating to the shale gas industry, this paper has utilised a combination of industry accounts and primary data, comprising three semi-structured surveys, targeted upon suppliers, landowners and employees, in order to generate multiplier estimates. The fieldwork was completed between June and September 2012. Given the relatively small numbers of landowners and employees, even when including agency workers and contractors, the entire populations were surveyed. In contrast, given the larger supply chain population, a sample was selected comprising the 323 most significant firms, which represented approximately three quarters of shale gas supply chain expenditure. Response rates ranged from $47 \%$ for landowners (7/15), $25 \%$ for employees $(21 / 84)$, and $12 \%$ for suppliers (39/323).

All surveyed groups were asked to recount their patterns of expenditure and the spatial distribution, together with an estimate of savings. This approach meets the concerns raised by KINNAMAN (2011:1244-5), in that previous studies tend to assume that all income is spent immediately, which then exaggerates immediate economic impact. Whilst savings might provide an economic injection at a later date (as per the relative income model, the permanent 
income model and the life cycle model), it is a short term leakage from the local economy. This is a particularly significant question for landowners, who receive licence fees and/or rental income. Economic theory suggests that this type of windfall earnings tend to be saved, rather than spent immediately (THALER, 1990). Moreover, even when spent, the probability of the local or even regional economy specialising in whatever luxury good thereby purchased is remote, outside of using this to finance an upgrade via the residential housing market. However, it is also of significance for employees, particularly those travelling away from their home area for temporary work on exploration or drilling gas wells. These employees may receive higher than normal rewards to compensate them for this personal dislocation, and hence these may be treated as windfall earnings and either redistributed in full to their home area, or a significant proportion saved and not spent in the immediate time period. Either one of these results would reduce the local economic impact experienced in the host region.

Cuadrilla company monthly expenditure accounts, totalling US $\$ 10.1 \mathrm{~m}(£ 6 \mathrm{~m})$, for July 2012 , indicated that approximately $30.1 \%$ of expenditure was accounted by direct and indirect (consultancy or agency) employment, $69.7 \%$ by the remainder of the supply chain and a mere $0.2 \%$ by payments to landowners. Apart from national insurance payments for direct employees, there were no tax liabilities included in the accounts, due to the loss making aspect inherent in the exploration phase of operations.

Landowners: Respondents claimed to spend all received income (after tax) within a 12 month period, with approximately $86 \%$ occurring within the North West regional and $50 \%$ within Lancashire. Given that this data derived from relatively modest licence fees relating to test drilling, representing only $0.2 \%$ of industry monthly expenditure, this result is plausible. However, the expansion of production, and potentially higher future licence payments, may 
result in a higher propensity to save and expenditure on more luxury goods outside the local economy, resulting in a lower local income multiplier. License payments will remain essentially modest, compared with the US, because UK law holds that the Crown owns oil and gas reserves rather than landowners under whose land the national resources may be located. Nevertheless, payments to landowners would be expected to increase once access to transportation and full drilling rigs were negotiated, as opposed to small scale test drilling.

Suppliers: The sample of 323 firms represented three-quarters of the Bowland field industry supply chain by value, at the time of survey, accounting for an annualised $£ 19.98$ million of expenditure. Of these, only 38 suppliers were located in Lancashire, representing $£ 388,201$ and $1.94 \%$ of total supply chain value, whilst the North West region comprised 57 firms and $£ 822,445$ expenditure, representing $4.12 \%$ of total supply chain value. By contrast, the 45 international firms received just over $£ 2$ million worth of orders and represented just over a tenth of total supply chain value (see Table Two). This is actually considerably less of a leakage from the UK economy than the $29 \%$ predicted by AMEC (2013:69) and the $33 \%$ by REGENERIS (2012:36), although the reason for this difference could simply relate to the different stages of development examined in each study.

Table 2: Regional Distribution of Bowland Field Supply Chain Expenditure, July 2012

\begin{tabular}{clcc}
\hline No of firms & Selected Regions & Value (£’000) & \% total supply chain expenditure \\
\hline 38 & Lancashire & 388.2 & 1.94 \\
57 & NorthWest & 822.4 & 4.12 \\
\hline 24 & London \& SE & 9381.2 & 46.95 \\
16 & Aberdeen & 581.0 & 2.91 \\
26 & Yorkshire & 274.5 & 1.37 \\
88 & Midlands (E \& W) + & 4853.3 & 24.29 \\
& Lincolnshire & & \\
\end{tabular}




\begin{tabular}{cccc}
\hline 29 & Other UK & 1679.4 & 8.40 \\
\hline 45 & Overseas & 2002.3 & 10.02 \\
\hline 323 & TOTAL & 19982.3 & 100.00 \\
\hline
\end{tabular}

The data indicates that local supply clusters remain undeveloped, which is not surprising for an infant industry. Expenditure occurring within the home region was disproportionately weighted towards hospitality and leisure, equipment and plant hire, electrical and civil engineering contractors and training services, with only a few examples of product sales related to drilling activities. The vast majority of suppliers within Lancashire (84.2\%) and the North West $(87.7 \%)$ were independent entities, and not subsidiaries or branches of larger organisations with head offices elsewhere in the UK or located abroad. Hence, this might be expected to result in greater local spending propensities. However, future expansion is likely to attract the establishment of new firms, or the opening of branch offices, to operate closer to the end customer. Future studies will have to take into account the differences between subsidiaries where activity takes place and value is created, within the local economy, and those which largely coordinate activity taking place elsewhere, thereby repatriating value and profits to the home region.

In terms of those responding to the survey, three quarters provided drilling, power and civil engineering equipment and associated consultancy services, whilst the remainder represented support services such as human resources, hospitality, financial and legal services. Whilst $21.3 \%$ of second-level expenditure by supply chain firms was reported to have occurred in the Lancashire area, this is over-inflated by the over-representation of Lancashire firms amongst respondents, given the fact that their spending patterns differed markedly from non-Lancashire respondents, who spent far less in the Lancashire economy (see FIG 1). Consequently, if the 
weighting of Lancashire respondents is adjusted to more accurately reflect the total population, the adjusted share of supply chain second-level spending occurring within Lancashire falls to $16.7 \%$. Thus, it would appear clear that the development of an integrated cluster of suppliers, to serve the shale gas industry developing in the Lancashire region, would benefit not only the firms directly involved, but also the wider community though this purchasing pattern.

FIG 1: The Second-Level Spatial Distribution of Expenditure (after tax and dividend payments) Reported by Individual Firms within the Bowland Shale Gas Supply Chain, June-September 2012

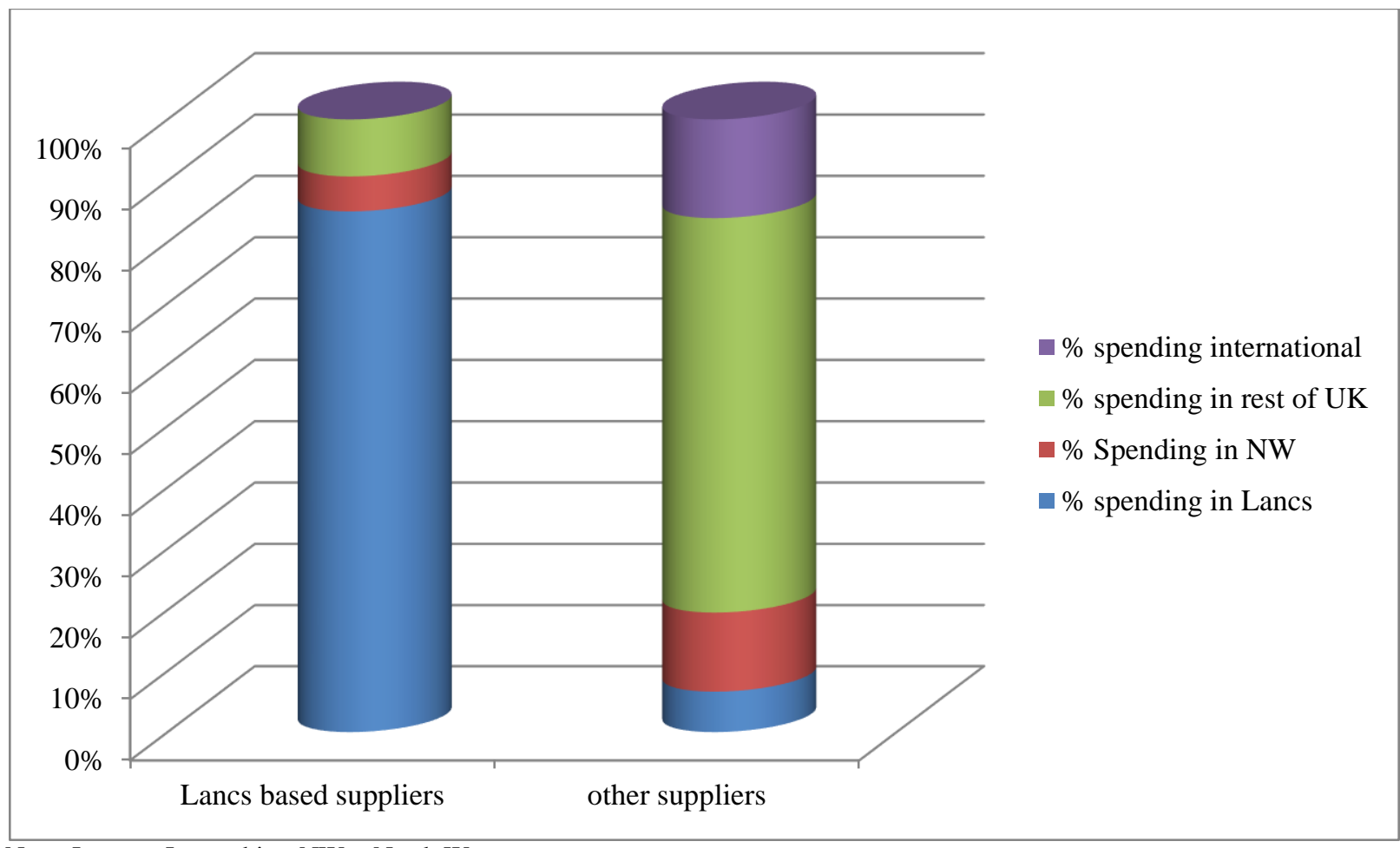

Note: Lancs $=$ Lancashire; $\mathrm{NW}=$ North West.

Employees: The vast majority of individuals who have undertaken work for the shale gas industry in Lancashire over the past 12 months have been employed on a temporary basis, either through agency or consultancy contracts, rather than direct employees. As such, only 5\% of respondents actually lived in the Lancashire area, with the remainder residing elsewhere and working in the Bowland field for only short periods of time. As a result, $74 \%$ of respondent 
income was transferred back to the home region (to dependant families), with a further $18 \%$ saved and leaving only around $8 \%$ to be spent in Lancashire. There was a significant difference in spatial expenditure patterns between Lancashire residents, who reported spending threequarters of their income within a 12 month period within the local area, and non-Lancashire residents. Of the latter, those who were located in the Bowland field for the majority of their working time spent $18.5 \%$ of their income in Lancashire, whilst the equivalent figure for those working only occasionally in the Bowland field was a meagre $1.1 \%$ of income.

These figures are likely to over-estimate the consumer expenditure local multiplier effect, however, because of an omission in the survey design to ascertain what proportion of 'local' spending took place in national chains as opposed to independent enterprises, as the former have been noted to have far lower subsequent local expenditure than the latter (COMPETITION COMMISSION, 2000:para 13.74; LA TROBE, 2002). For example, chain stores and supermarkets, with their national or international supply chains and integrated distribution arrangements, spent only between $11 \%$ and $14 \%$ in the local area, whereas, at the other extreme, local organic box schemes have been found to generate local multiplier values of 2.5 (SACHS, 2002:115-7; WARD and LEWIS, 2002:20). Another study found that independent and locally-owned retailers spent $52 \%$ of their revenue within the local area, compared to $13.6 \%$ for national chains, whereas for the restaurant sector, the equivalent results were $78.6 \%$ and $30.4 \%$ respectively (Civic Economics, 2012). The result of this literature, therefore, would be to moderate predicted multiplier estimates, based upon consumer reporting, as a certain proportion of consumer expenditure directed in the local area would be spent in national chains, and therefore have a lesser local impact. 
Notwithstanding this qualification, the employment of local residents, or the encouragement of non-residents to relocate to the region, would appear to be significant determinants of the potential local economic impact arising from the expansion of shale gas extraction. This is potentially problematic, because gas extraction has traditionally relied upon a particularly flexible labour supply, comprising a core group of directly employed individuals, augmented by short-term contract workers and consultants often only working in an area for a period of weeks whilst drilling occurs in specific wells (JACQUET, 2011). Consequently, the provision of training and skills development for local residents, is a significant factor in the retention of local economic value arising from the shale gas industry.

Calculating the Local Economic Impact: The total economic injection into the regional economy will depend upon; (i) the direct expenditure undertaken by the shale gas industry through its supply chain, (ii) the indirect effects arising from those suppliers increasing their own expenditure as a result of this increase in demand for their products and services, and (iii) the induced effect deriving from the increased consumption related to this raised level of economic activity, due either to existing workers receiving higher remuneration or additional workers being recruited to meet the higher levels of demand. Utilising the simple Keynesian multiplier model, developed earlier in the paper;

$\mathrm{Y}_{\mathrm{r}}=\mathrm{k}\left(\bar{C}_{\mathrm{r}}+\mathrm{I}_{\mathrm{r}}+\mathrm{G}_{\mathrm{r}}+\mathrm{X}_{\mathrm{r}}-\bar{M}_{\mathrm{r}}\right)$

Where

$$
\mathrm{k}=\frac{1}{1-(\mathrm{c}-\mathrm{m}+\mathrm{i})(1-\mathrm{t})}
$$


The local economic impact arising from the expansion of the shale gas industry can be calculated by substituting that proportion of spending arising from the shale gas industry which occurs within Lancashire into the main body of the equation, and the multiplier calculated by reference to the marginal propensity to consume and invest locally, less the negative impact of taxation upon effective local demand. In the early prospective phase of operations, taxation was not a significant factor, since explorative operations do not make a profit and therefore only employment and property taxes were levied. Consequently, the model is simplified by excluding tax effects at this early stage in operations. At the point where the shale gas industry begins to make significant profits, taxes will act as a net withdrawal from the local economy unless the full tax take is recycled into additional public expenditure. There is no current proposal for this to occur and therefore the regional multiplier will be lowered as a result.

Evidence derived from the three surveys undertaken for this paper indicate that $1.94 \%$ of supply chain expenditure went to local firms, whilst $5 \%$ of employee consumption spending and $50 \%$ of payments to landowners occurred in Lancashire. Given that industry accounts state that $69.7 \%$ of current Bowland field shale gas expenditure is allocated to the supply chain, $30.1 \%$ to employment and consultancy, with a further $0.2 \%$ given in payments to landowners, it is therefore possible to weight the local spending estimates thus:

i. $\quad$ Local supply chain expenditure proportion $=1.94 \times 0.697=1.35$

ii. Employee local spending proportion $=5 \times 0.301=1.51$

iii. Landowner local spending proportion $=50 \times 0.002=0.1$

Thus, the proportion of current expenditure benefitting the Lancashire area is given by $1.35+$ $1.51+0.1=2.96 \%$. Thus, $97 \%$ of this expenditure flows immediately outside of Lancashire. As an infant industry, Bowland shale gas currently spends all of its income and, whilst this 
pattern would be most unlikely to persist in a more mature industry (given the need to reward investors and pay tax liabilities), employing the simplifying assumption that this continued in the medium term would establish the maximum potential local economic impact. Accordingly, if the Cuadrilla estimate of potential realisable shale gas revenue of $£ 120 \mathrm{bn}$ is accurate, then the maximum anticipated benefit to Lancashire would be around $£ 3.55 \mathrm{bn}$, if current spending patterns were to be maintained. If dividend payments and taxation transferred a proportion of revenues outside of the Lancashire region, then this initial boost would be commensurably smaller. In either case, the multiplier effect would magnify this initial boost to the local economy.

To calculate the multiplier, the survey evidence points towards the marginal propensity to spend locally, on behalf of the supply chain, as 0.167 , employee-consumers as 0.08 and landowners 0.5 . Once again, when these are weighted to account for their share of total shale gas spending (as above), these values become $0.113+0.024+0.001=0.138$. Hence,

$$
\mathrm{k}=\frac{1}{\frac{1-0.138}{1-16}}=1.16
$$

Thus, the initial impact arising from shale gas expenditure in the local area should be inflated by a multiplier of 1.16 , implying that the anticipated economic benefit to Lancashire would be $£ 4.12$ bn (i.e. $£ 3.55$ bn $x 1.16$ ), spread over the life span of shale gas extraction. If the extraction period is assumed to take place over two decades, then this would be the equivalent of an average $£ 0.2$ bn per year. This multiplier estimate is much lower than the estimates produced for US shale gas extraction, however, survey evidence suggests that the majority of industry 
expenditure took place within the State where extraction occurred, which is significantly different from the emerging shale gas industry in Lancashire (CONSIDINE, 2010).

It is important to acknowledge that this multiplier estimate relies upon data drawn from the initial exploration phase of an infant industry, and hence it is probable that relative weightings will change substantially if the industry expands as anticipated. In addition, once the industry records larger profits than it does currently, during the exploration phase, then national taxation will act as an additional leakage from the local economy, thus reducing the local multiplier. However, the significance of this prediction, when related to the forecast total value of the extractable shale gas reserves in the Bowland field of up to $£ 120 \mathrm{bn}$, highlights the importance of leakages from the local economy. Unless or until a greater proportion of the supply chain becomes resident within the local economy, and/or present reliance upon temporary contracts for non-resident workers is superseded through the provision of skills training to equip local employees to fill vacancies, the local economy will capture only a small proportion of the overall economic benefits arising from the expansion of the industry. In the absence of these changes, as previously noted, almost $97 \%$ of expenditure on shale gas exploration in Lancashire will flow elsewhere in the UK and abroad, thereby not directly benefitting the locality.

In order to illustrate how embedding the emergent shale gas industry within the local economy could have a significant economic impact, it would be possible to re-estimate the multiplier calculation on the basis of an assumption that, in the future, one third of all employees reside within Lancashire and one third of the supply chain by value has relocated within the Lancashire area. This assumption has not been selected at random, but follows the work of FEYRER ET AL (2015), in their analysis of regional economic impact derived from shale gas in the USA. Given this assumption, because it has been demonstrated that local employees and 
firms spend more of their income within the local area, ceteris paribus, the weighted calculation becomes $20.91+9.03+0.1=30.04$, whilst the multiplier rises to,

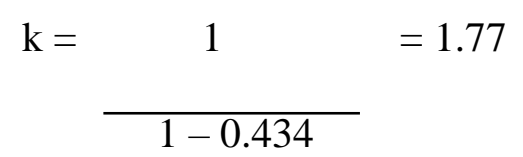

Thus, the value of embedding a greater proportion of the supply chain and workforce within the local economy would result in the predicted total local economic impact rising to $£ 30.04 \mathrm{x}$ $1.77=£ 53.17 \mathrm{bn}$, or an average of $£ 2.66 \mathrm{bn}$ per year spread over twenty years. This would represent a significant additional boost to the Lancashire economy. Consequently, whether or not it would prove possible to meet or exceed a target of perhaps one third of all supply chain value and employee residing within the local economy, this example emphasises the difference, for local stakeholders, between hosting or embedding an emergent energy industry within their community.

\section{Discussion and Policy Implications}

The data utilised in this paper is drawn from the initial exploration phase of an infant industry, and consequently it is anticipated that relative cost weightings will change substantially if the industry expands as anticipated. Nevertheless, whilst precise estimates will change, as the industry develops, the significance of the analysis contained in this paper is to highlight the importance of leakages in determining the magnitude of local economic impact, and therefore these findings should inform the deliberations of national and local policy makers intending to enhance benefits to the local economy. Whilst the Lancashire Local Economic Partnership City 
Deal has outlined "significant opportunities" deriving from shale gas expansion in the region, with the energy sector being identified as a key component for growth, jobs and skills development $^{\mathrm{v}}$, this is only realisable if it is possible to embed the emergent industry more closely within the local economy. Otherwise, the vast majority of economic benefits will accrue outside of the region.

Current expenditure patterns within the infant shale gas industry would indicate that the vast majority of economic value created by the Bowland shale gas industry would benefit the national economy, as only around $10 \%$ of the supply chain and a few highly specialised workers were drawn from abroad. Hence, it is perhaps unsurprising that national government perceives significant national advantages to the promotion of shale gas expansion, whether due to concerns over energy security, potential tax revenue, employment opportunities or the enhancement of labour productivity. Nevertheless, since the cost (externalities) of extraction will be borne within specific localities, it would seem appropriate for local stakeholders to explore how a greater proportion of economic benefits can be captured within the local economy. Moreover, given that Lancashire has below average levels of GVA per capita, and the national government is committed to rebalancing the UK economy, there would appear to be ample justification for policy intervention to shift the regional economy out of an underperforming growth path (ASHE, 2012; HM TREASURY, 2014:12).

Currently, less than $2 \%$ of Bowland field supply chain value is located within the local economy, and only a little over $4 \%$ in the wider region, whilst only $5 \%$ of the workforce is drawn from the local community. This has to change significantly, as the industry expands, if economic advantages are to be captured by the local community who will have to bear the brunt of such external costs as may accompany an energy extraction industry. However, the 
existence of established offshore oil and gas supply chain clusters focused upon Aberdeen, which benefitted from its locational advantages for North Sea offshore exploration, may make it less certain that a supply chain will automatically develop within close proximity to the Bowland field (CUMBERS et al., 2003). Existing path dependency, for emergent industries in unconventional gas extraction, could result in a reluctance, amongst the existing oil and gas supply chains, to relocate and thereby embed significant elements of their operations to Lancashire in order to service the shale gas industry in the Bowland field. Similarly, it might prove to be simpler and more cost effective to attract existing skilled workers from their current work in the offshore industry, to fulfil the workforce requirements of the emergent shale gas industry, rather than to seek to train Lancashire residents. Perhaps surprisingly, the current distribution of supply chain expenditure does not indicate the anticipated 'Aberdeen effect' (see Table 2), although, as the industry expands, this may become more noticeable over time.

Policy intervention may, therefore, be required to facilitate the emergence of a viable supply cluster in Lancashire, in order to anchor deeper economic gains. This may include targeted fiscal incentives, dependent upon the spatial location of corporate activity (by value), or to build up local partnerships between business and universities, in order to create support networks and R\&D spillovers which might attract inward investment.

A second area where policy intervention may be required concerns human capital development intended to meet the workforce requirements of the emergent shale gas industry, and thereby boost local economic impact through creating employment opportunities for the local community. Skills shortages and labour force bottlenecks have already been identified, even at this early stage of industry expansion, as the primary factor limiting growth in their organisation (IOD, 2013:18,144). This mirrors the experience of the US shale gas industry, 
which resulted in the formation of a number of bespoke training programmes in the regions where shale exploration was concentrated. Notable examples include those developed by Nicholls State University, Louisiana (Petroleum Services Programme) and the Shale Training and Education Centre, formed out of a partnership between Pennsylvania College of Technology and Penn State Education (JACQUET, 2011:1-2,15-16; MSETC, 2011:28).

In the UK, partnerships with local higher education providers has been identified as of key importance in reducing labour supply constraints (AMEC, 2013:xiv,50,83-4; HCECCC, 2013:38). Current suggestions have mooted the development of specialist colleges to meet some of the skills requirements of the shale gas industry, possibly beginning with an expansion of Blackpool and Fylde College ${ }^{\text {vi }}$ However, these suggestions remain underdeveloped both in terms of the level of resourcing and whether educational partnerships will be narrowly focused upon low level core skills or embrace graduate level provision and/or the funding of research germane to the operation of the industry and adaptation of local communities. For example, whilst Blackpool and Fylde College may receive a potential investment of $£ 6.2$ million, this is not sufficient to replicate the training and research programmes established in the USA. For example, the ShaleTec/MSETC centre alone benefitted from Federal and State grants totalling $£ 10.5$ million (US\$17.6 million) (MSETC, 2011:52).

One solution might be to hypothecate part of the support provided to facilitate the development of the shale gas industry (HM TREASURY, 2013:39, 2014:58) to funding the development of comparative training programmes in the Bowland field. This may provide better targeted support than the tax reductions, announced in the 2014 budget (HM TREASURY, 2014:35), which have been challenged as 'questionable' by the House of Lords Economic Affairs Committee, given that cost was not presented as a significant barrier to expansion, in evidence 
put before the committee (HLEAC, 2014a:39, Ev169-170). However, even if sufficient resourcing is provided, by a combination of industry and public sources, there will be a time lag even if these plans are ultimately enacted and, in the meantime, the attraction of skilled labour into the region could mitigate supply constraints but at the expense of other industries operating on other regions (GILMARTIN AND ALLAN, 2015:338).

One final element, contributing towards local economic benefit, has been proposed by the shale gas industry itself, via its Community Charter. Through this, the industry has proposed the provision of $£ 100,000$ in community benefits for each well site where fracking occurs, and $1 \%$ of revenues to local and regional communities; the latter split two-thirds to local and one-third to county levels (UKOOG, 2014). One estimate suggests that this could provide between $£ 3$ to $£ 12$ million of initial benefit to local communities, with a further $£ 0.3$ to $£ 0.6$ billion arising from production contributions, depending upon the size and duration of extraction (AMEC, 2013:84,122). The shale gas Charter in many ways reflects the 2011 Community Benefit Protocol (updated in 2013), whereby the onshore wind energy industry has committed to providing a minimum local community benefit of $£ 5,000$ per megawatt of energy generated, for the lifetime of future projects (RENEWABLEUK, 2013; DECC, 2014). Benefits can take the form of the direct provision of community facilities or environmental improvements, or through the establishment of community funds, perhaps through a form of profit sharing. These community payments, are, naturally, tax deductable (WoOD, 2014).

The precise magnitude and mode of distribution of this community benefit remains unresolved. Moreover, this concession has not been particularly well received, with certain Members of Parliament describing it as 'derisory' and the Local Government Association rejecting it as insufficient (HLEAC, 2014a:36; Ev147-8). This may simply reflect the start of a bargaining 
process, between industry and representatives of local stakeholders, to extract greater local benefit. Yet this has also resulted in national government raising the possibility that local authorities, in affected areas, might be able to retain $100 \%$ (as opposed to the usual $50 \%$ ) of business rates, related to shale gas operations (HLEAC, 2014a:38; 2014b:Ev166). However, even were this to be developed into a firm proposal, it is probable that any such arrangements would be investigated by the European Commission, pertaining to whether this qualifies as state subsidy, which is prohibited under single market legislation. ${ }^{\text {vii }}$ This eventuality depends upon the form of relationship the UK negotiates with the European Union following the completion of withdrawal; reliance upon a Free Trade Agreement or trading under World Trade Organisation rules would remove this potential scrutiny, however application for membership of the European Economic Area (EEA) would not.

\section{Conclusion}

This paper has sought to estimate the potential local economic impact likely to arise from the expansion of an infant unconventional gas extraction industry. The data used is limited, given the absence of I-O tables for English regions. This paper relies upon a combination of survey evidence and industry expenditure accounts, and utilises a simple Keynesian multiplier model, as this is better fitted to the current state of the data. If the industry expands to the point that it is included as a separate entity in I-O tables, then these more advanced methods can be utilised to calculate more detailed estimates of economic impact, certainly at the national level. Moreover, it is also important to acknowledge that, as the industry expands, it is anticipated that relative cost weightings will change substantially and hence estimates of economic impact will alter accordingly. However, none of these shortcomings detract from the focus of the paper, which is to use such data as is currently available to inform local stakeholders of the likely economic benefits that may derive from any expansion of the shale gas industry in their 
area. If these stakeholders wish to shape the future development of the industry within their local economy, or wish to negotiate with national authorities over a fair distribution of the broader economic benefits arising from the development of unconventional gas extraction, they need to have the best available estimates concerning how to maximise local advantages. It is in this regard that this paper seeks to contribute.

The proposed expansion of shale gas extraction has been championed at national level, by government and industry sources, on the basis that it has the potential to deliver a number of macroeconomic benefits. However, the potential economic benefit for those communities experiencing the negative externalities associated with energy extraction, has received less attention. As the analysis in this paper demonstrates, the expansion of the shale gas industry will not automatically deliver significant economic benefits to the local economies in which it operates, unless supply chains are embedded more firmly within the region and unless a higher proportion of the workforce is drawn from the local community. Given the existence of energy clusters centred upon Aberdeen, it may be difficult to establish a separate shale gas specialised supply chain focused upon Lancashire, without the creation of a favourable institutional structure to facilitate the development of this new cluster. Similarly, the prevention of labour force bottlenecks, solved by short term inflow of specialised labour from outside the region, will require significant investment in training in partnership between industry and local educational providers. This should boost the skills profile of the local workforce, and create greater knowledge spillovers to the wider benefit of other firms within the area, but should boost levels of demand in the region, through direct, indirect and induced effects.

The resource implications for these initiatives could be met through hypothecation of (or ring fencing) part of the existing UK national government support for the shale gas industry to 
facilitate labour force development and/or encourage supply chain clusters to develop closer to the industry they intend to service. If so, this should contribute towards advancing human capital development, with macroeconomic benefits for growth and employability, but also in terms of rebalancing the UK economy, through promoting activity within an area with lower than average per capital GVA. The local economic impact estimates, produced in this paper, are intended to inform, and thereby contribute towards, this policy deliberation through the enhancement of the evidence base.

\section{Acknowledgements:}

The author wishes to thank Cuadrilla Resources for their sponsorship of an earlier consultancy contract and for the access of corporate data in order to facilitate the accuracy of the impact calculations contained within this paper.

\section{Bibliography}

ACKERMAN, F. (2002) Still dead after all these years: Interpreting the failure of general equilibrium theory, Journal of Economic Methodology 9(2), 119-139.

Allan, G., McGregor, P. And Swales, K. (2011) The importance of revenue sharing for the local economic impacts of a renewable energy project: A social accounting matrix approach, Regional Studies 45(9), 1171-1186. 
ALLAN, G.J. 2015. The regional economic impacts of biofuels: A review of multisectoral modelling techniques and evaluation of applications, Regional Studies, 49(4): 615-643.

Allcott, H. AND Keniston, D. (2014), Dutch Disease of Agglomeration? The local economic effects of natural resource booms in modern America, NBER Working Paper No. w20508 (available at: http://www.nber.org/papers/w20508).

AMEC [AMEC ENVIRONMENT \& INFRASTRUCtURE UK LIMITED] (2013) Strategic Environmental Assessment for Further Onshore Oil and Gas Licensing: Environmental Report, London: Department of Energy and Climate Change (available at: https://www.gov.uk/government/uploads/system/uploads/attachment_data/file/273997/DECC _SEA_Environmental_Report.pdf).

ANDREWS, I.J. (2013) The Carboniferous Bowland Shale Gas Study: Geology and Resource Estimation, London: British Geological Survey for the Department of Energy and Climate Change (available at: https://www.gov.uk/government/uploads/system/uploads/attachment_data/file/226874/BGS DECC_BowlandShaleGasReport_MAIN_REPORT.pdf).

Armstrong, H. And TAYlor, J. (2000), Regional Economics and Policy, Oxford: Blackwell, pp. 8-15.

ASHE [ANnUAl Survey of Hours And EARnings] (2012) Region and Country Profiles Economy, London: Office of National Statistics (available at: 
http://www.ons.gov.uk/ons/guide-method/surveys/list-of-

surveys/survey.html?survey=Annual+Survey+of+Hours+and+Earnings+(ASHE).

AudRETSCH, D.B. AND FELDMAN, M.P. (1996) R\&D spillovers and geography of innovation and production, American Economic Review, 86(3): 630-640.

Bolton, P. (2014) Energy prices, Parliamentary Briefing Paper SN/SG/4153, London: The Stationary Office (available at: www.parliament.uk/briefing-papers/sn04153.pdf).

Boschma, R. (2005) Proximity and innovation: A critical assessment, Regional Studies 39(1), $61-74$.

BREKKE, T. (2015) Entrepreneurship and path dependency in regional development, Entrepreneurship and Regional Development, 27(3-4), 202-218.

Civic Economics (2012) Indie Impact Study Series: A National Comparative Survey with the American Booksellers Association - Salt Lake City, Utah, Chicago: Civic Economics (available at: http://localfirst.org/images/stories/SLC-Final-Impact-Study-Series.pdf).

COMPETITION COMMISSION (2000) Supermarkets: A Report on the Supply of Groceries from Multiple Stores in the United Kingdom - Vol 2, London: Competition Commission (available at: http://webarchive.nationalarchives.gov.uk/+/http:/www.competitioncommission.org.uk/rep_pub/reports/2000/446super.htm\#full). 
Considine, T.J. (2010) The Economic Impacts of the Marcellus Shale: Implications for New York, Pennsylvania and West Virginia, Washington DC: American Petroleum Institute (available at: http://www.api.org/ /media/Files/Policy/Exploration/API-Economic-ImpactsMarcellus-Shale.ashx

Considine, T.J., Watson, R., Entler, R. And Sparks, J. (2009) An Emerging Giant: Prospects and Economic Impacts of Developing the Marcellus Shale Natural Gas Play, Pennsylvania: Department of Energy and Mineral Engineering, Pennsylvania State University.

Considine, T.J., Watson, R. And Blumsack, S. (2010) The Economic Impacts of the Pennsylvania Marcellus Shale Natural Gas Play: An Update, Pennsylvania: Department of Energy and Mineral Engineering, Pennsylvania State University.

Courtney, P., Hill, G. AND Roberts, D. (2006) The role of natural heritage in rural development: An analysis of economic linkages in Scotland, Journal of Rural Studies 22, 469484.

Cumbers, A., Mackinnon, D., AND Chapman, K. (2003) Innovation, collaboration, and learning in regional clusters: A study of SMEs in the Aberdeen oil complex, Environment and Planning A 35(9), 1689-1706.

DECC [DePARTMENT OF ENERGy AND Climate Change] (2014a) The Jurassic Shales of the Weald Basin: Geology and Shale Oil and Shale Gas Resource Estimation, London: The Stationary Office (available at: 
https://www.gov.uk/government/uploads/system/uploads/attachment_data/file/313701/BGS

DECC_JurassicWealdShale_study_2014_MAIN_REPORT.pdf).

DECC [DEPARTMENT OF ENERGY AND Climate ChAnge] (2014b) Community Benefits from Onshore Wind Developments: Best Practice Guidance for England, London: The Stationary Office (available at: https://www.gov.uk/government/publications/community-benefits-and-engagement-guidance-foronshore-wind).

DomANSKI, B. AND GwOSDZ, K. (2010) Multiplier effects in local and regional development, Quaestiones Geographicae 29(2), 27-37.

Dow, S.G. AND RodRIGUEZ-FuETES, C.J. (1997) Regional finance: A survey, Regional Studies 31(9), 903-920.

EY [ERneST AND Young] (2014) Getting Ready for UK Shale Gas: Supply Chain and Skills Requirements, London: Ernest and Young (available at: http://www.ukoog.org.uk/images/ukoog/pdfs/Getting_ready_for_UK_shale2_gas_FINAL202 2.04.14.pdf).

Faggian, A. AND BiAgi, B. (2003) Measuring Regional Multipliers: A Comparison Between Two Different Methodologies for the Case of the Italian Regions. ERSA Conference Papers, $\begin{array}{llll}\text { ERSA03: } & 249 & \text { (available } & \text { at }\end{array}$ wien.ac.at/ersa/ersaconfs/ersa03/cdrom/papers/249.pdf). 
FEYRER, J., MANSUR, E.T. AND SACERDOTE, B. (2015), Geographic Distribution of Economic Shocks: Evidence from the fracking revolution, NBER Working Paper No. 21624 (available at: http://www.nber.org/papers/w21624).

GÉNY, F. (2010) Can Unconventional Gas be a Game Changer in European Gas Markets?, Oxford: Oxford Institute for Energy Studies (available at: http://www.oxfordenergy.org/wpcms/wp-content/uploads/2011/01/NG46-

CanUnconventionalGasbeaGameChangerinEuropeanGasMarkets-FlorenceGeny-2010.pdf).

Gilmartin, M. AND Allan, G. (2015) Regional employment impacts of marine energy in the Scottish economy: A general equilibrium approach, Regional Studies, 49(2), 337-355.

Green, C.A., Styles, P. And BAptie, B.J. (2012) Preese Hall Shale Gas Fracturing: Review and Recommendations for Induced Seismic Mitigation, London: Department of Energy and $\begin{array}{lll}\text { Climate } & \text { Change available }\end{array}$ http://og.decc.gov.uk/en/olgs/cms/explorationpro/onshore/cuadrilla_decc/cuadrilla_decc.aspx \# www.decc.gov.uk/.gas/5055-preese-hall-shale-gas-fracturing-review).

HM TREASURY (2014) Budget 2014, London: The Stationary Office (available at: https://www.gov.uk/government/uploads/system/uploads/attachment_data/file/293759/37630 _Budget_2014_Web_Accessible.pdf).

HM Treasury (2013) Autumn Statement 2013, Cm. 8747, London: The Stationary Office (available at: 
https://www.gov.uk/government/uploads/system/uploads/attachment_data/file/263942/35062 _Autumn_Statement_2013.pdf).

HCECCC [House of Commons Energy and Climate Change Committee] (2013) The Impact of Shale Gas on Energy Markets, HC 785, London: The Stationary Office (available at: http://www.publications.parliament.uk/pa/cm201213/cmselect/cmenergy/785/785.pdf).

HLEAC [House of LORDS ECONOMIC AFFAIRS COMmitTEe] (2014a) The Economic Impact on UK Energy Policy of Shale Gas and Oil, HL 172, London: The Stationary Office (available at: http://www.publications.parliament.uk/pa/ld201314/ldselect/ldeconaf/172/172.pdf).

HLEAC [HOUSE OF LORDS ECONOMIC AFFAIRS COMMITTEE] (2014b) The Economic Impact on UK Energy Policy of Shale Gas and Oil: Appendix - Oral and Written Evidence, HL 172, London: The Stationary Office (available at: http://www.parliament.uk/documents/lordscommittees/economic-affairs/EnergyPolicy/EAC-energy-ev-vol.pdf).

IOD [Institute OF DiRECTORS] (2013) Getting Shale Gas Working, London: IOD (available at: $\quad$ http://www.iod.com/influencing/policy-papers/infrastructure/infrastructure-for-businessgetting-shale-gas-working).

ISAKSEN, A. (2015) Industrial development in thin regions: Trapped in path extension?, Journal of Economic Geography 15(3), 585-600.

JACQUET, J. (2011) Workforce Development Challenges in the Natural Gas Industry, City and Regional Planning Working Paper Series, Cornell University, New York. 
KInNAmAn, T. C. (2011) The economic impact of shale gas extraction: A review of existing studies, Ecological Economics 70, 1243-1249.

LA Trobe, H. (2002) Local Food, Future Directions, London: Friends of the Earth.

LEONTIEF, V. (1986) Input-Output Economics, Oxford: Oxford University Press, Second Edition.

Lewis, J.A. (1988), 'Economic Impact Analysis: A UK literature survey and bibliography', Progress in Planning, 30: 157-209.

MARCHAND, J. (2012), 'Local labor Market Impacts of Energy Boom-Bust-Boom in Western Canada', Journal of Urban Economics, 71(1): 165-174.

MARTIN, R. (2010) Roepke lecture in economic geography: Rethinking regional path dependence: beyond lock-in to evolution, Economic Geography 86(1), 1-27.

MARTin, R. AND SunLey, P. (2006) Path dependence and regional economic evolution, Journal of Economic Geography 6(4), 395-437.

Mason, C.F., Muehlenbachs, L.A. and Olmstead, S.M. (2015), The Economics of Shale Gas Development, RFF Discussion Paper No.14-42-REV (available at: http://www.rff.org/files/sharepoint/WorkImages/Download/RFF-DP-14-42.pdf). 
McCAnn, P. (2013), Modern Urban and Regional Economics, Oxford: OUP, pp. 166-181.

MiLler, R.E. AND BlaIR, P.D. (2009) Input-Output Analysis: Foundations and Extensions, Cambridge: Cambridge University Press.

MSETC (2011) Pennsylvania Marcellus Shale Workforce Needs Assessment, Pennsylvania: Marcellus Shale Education and Training Centre (available at: http://www.shaletec.org/docs/PennsylvaniaStatewideWorkforceAssessmentv1_Final.pdf\#zoo $\underline{m=75})$.

ONS [OfFice FOR NATIONAL Statistics] (2014) UK Input-Output Analytical Tables Detailed, 2010 (available at: http://www.ons.gov.uk/ons/publications/re-referencetables.html?edition=tcm\%3A77-346757).

PARTRIDGE, M.D. AND RICKMAN, D.S. (2010) Computable general equilibrium modelling for regional economic development analysis, Regional Studies 44(10), 1311-1328.

PSAltopoulos, D. AND ThOMSON, K. J. (1993) Input-Output evaluation of rural development: A forestry-centre application, Journal of Rural Studies 9(4), 351-358.

REGENERIS (2012) Economic Impact of Shale Gas Exploration and Production in Lancashire and the UK, Altringham: Regeneris (available at: http://www.cuadrillaresources.com/wpcontent/uploads/2012/02/Full_Report_Economic_Impact_of_Shale_Gas_14_Sept.pdf). 
RenewableUK (2013) Onshore Wind: Our Community Commitment, London: RenewableUK (available at: $\quad$ http://www.renewableuk.com/en/utilities/documentsummary.cfm?docid=3E03FD17-1D22-4945-9D8F9A019D949C7A).

RigBY, D.L. AND BROWN, W.M. (2015) Who benefits from agglomeration?, Regional Studies 49(1), 28-43.

RoBInson, S. (2006) Macro models and multipliers: Leontief, Stone, Keynes and CGE models, in DE JAnvry, A. And Kanbur, R. (Eds) Poverty, Inequality and Development: Essays in Honor of Erik Thorbecke, pp. 205-232, New York: Springer Science.

Rodgers, H. (2013) UK Shale Gas - Hype, Reality and Difficult Questions, Oxford: Oxford Institute for Energy Studies, University of Oxford (available at: http://www.oxfordenergy.org/wpcms/wp-content/uploads/2013/07/UK-Shale-GasGPC1.pdf).

SACHS, J. (2002) The Money Trail: Measuring Your Impact on the Local Economy using LM3 [Local Multiplier 3], London: New Economics Foundation (available at: http://www.pluggingtheleaks.org/downloads/the_money_trail.pdf).

SinClaiR M.T. AND SuTCLIFFE C.M. (1982), 'Keynesian Income Multipliers with first and second round effects: an application to tourist expenditure', Oxford Bulletin of Economics and Statistics, 44(4): 321-338. 
SinCLAIR M.T. AND SUTCLIFFE C.M. (1988), 'The estimation of Keynesian Income multipliers at the sub-national level', Applied Economics, 20: 1435-1444.

SNeAD, M.C. AND BARTA, S. (2008) The Local Impact of Oil and Gas Production and Drilling in Oklahoma. Oklahoma: Centre for Applied Research, Oklahoma State University.

THALER, R.H. (1990) Anomalies: Saving, fungibility, and mental accounts, Journal of Economic Perspectives 4(1), 193-205.

UKOOG [United Kingdom Onshore OpERATORS Group] (2014) Community Engagement Charter: Oil and gas from Unconventional Reservoirs (available at: http://www.ukoog.org.uk/images/ukoog/pdfs/communityengagementcharterversion6.pdf).

US ENERGy INFORMATION ADMINISTRATION (2011) World Shale Gas Resources: An Assessment of 14 Regions Outside the United States, Washington DC: US Department of Energy (available at: http://www.eia.gov/analysis/studies/worldshalegas/).

Ward, B. AND Lewis, J. (2002) Plugging the Leaks: Making the Most of Every Pound that Enters Your Local Economy, London: New Economics Foundation (available at: http://www.neweconomics.org/publications/entry/plugging-the-leaks).

Weinstein, A.L. AND PARTRIDGe, M.D. (2011) The Economic Value of Shale Natural Gas in Ohio, Ohio: Department of Agricultural, Environmental and Development Economics, Ohio State University. 
WEST, G.R. (1995) Comparison of input-output, input-output econometric and computable general equilibrium impacts at the regional level, Economic Systems Research 7(2), 209-227.

Wood, R., Gilbert, P., Sharmina, M. And Anderson, K. (2011) Shale Gas: A Provisional Assessment of Climate Change and Environmental Impacts, Manchester: The Tyndale Centre, University of Manchester available http://www.tyndall.ac.uk/sites/default/files/coop_shale_gas_report_final_200111.pdf).

Wood, I. (2014) UK Continental Shelf Maximising Recovery Review: Final Report, London: The Stationary Office available http://www.woodreview.co.uk/documents/UKCS\%20Maximising\%20Recovery\%20Review \%20FINAL\%2072pp\%20locked.pdf).

\section{Endnotes}

${ }^{\mathrm{i}}$ One British Thermal Unit (BTU) is the heat required to raise the temperature of one pound of water by one degree Fahrenheit. $1 \mathrm{mmBTU}$ equals a million BTU, and 1 trillion cubic feet (tcf) equals 1 billion mmBTU. Calculations are made at the prevalining exchange rate, $£ 1=$ US $\$ 1.68$.

ii http://www.cuadrillaresources.com/benefits/jobs-and-investment/

iii http://www.lancashire.gov.uk/media/897944/gva-local-article-2014.pdf. For statistical purposes, Lancashire is geographically defined according to the European Union nomenclature of units for territorial statistics (NUTS), level-2. This encompasses the twelve district councils that form the administrative focus of the County Council, together with Blackburn (with Darwen) and Blackpool.

${ }^{\text {iv }}$ For further explanation of the concept of Keynesian regional multipliers, Lewis (1988) provides a good overview. See also Sinclair and Sutcliffe (1982, 1988), Armstrong and Taylor (2000) and McCann (2013).

${ }^{\mathrm{v}}$ http://www.lancashirelep.co.uk/invest-in-lancashire/city-deal.aspx 
vihttps://www.gov.uk/government/uploads/system/uploads/attachment_data/file/327600/19_Lancashire_Growth

_Deal.pdf, p.7

viihttp://www.telegraph.co.uk/earth/energy/10580255/Government-accused-of-overhyping-shale-gas-

$\underline{\text { benefits.html }}$ 